\title{
Edward Bond and Drama in Education.
}

\author{
David DAVIS* \\ Birmingham City University
}

\begin{abstract}
The theme of this conference is the past, present and future of drama in education. I want to look at where we are today, then to give some brief attention to the influences from the theatre that have helped shape our work and finally to suggest that new forms of classroom drama are possible and in fact sorely needed. These influences, I will suggest, are also to be found in current developments in theatre form and in this case, the developments in theatre form made by the English playwright, Edward Bond. What those new forms are, I am not yet sure. This is likely to some extent to be frustrating for you, but I think the time is ripe to search for what they may be, even though I cannot yet give clear suggestions.
\end{abstract}

Two main paths have brought me to the position I want to share with you. One has been a growing concern about the direction in which drama form is being encouraged to go in the UK in some important areas. The other path has been the growing influence on me of the work of the playwright Edward Bond.

My concern about the direction in which drama in education in the UK is heading is based on several indicators. In fact, I want to argue that drama in education theory and practice has run into some difficulties at the present time. Teacher education courses in the UK have been stripped bare of the possibility of giving new teachers a thorough grounding in pedagogy, which is a vital basis for any teacher who wants to educate rather than deliver a prescribed curriculum. The cutting back of teaching time in the universities and the placement of students in schools means that students are apprenticed on the job with a certain amount of day release to get a smattering of teacher competencies. This 'apprenticeship' could be fine if all the host drama teachers were grounded in pedagogy and the theory and practice of teaching drama, and if they had time to teach the 'trainees', as they are now called. Even at its best, this is no substitute for a course that had the time and resources to open up for the students theories of art and drama, of teaching and learning, and of ways of knowing, and for all this to be taught through developing the skilled practice of the student teacher. The pressure to test and write attainment targets has had the tendency to drive what is taught in drama down to the level of examinable skills. In this climate it is understandable for teachers to reach for a formulaic approach.

One influence on this development has been the misuse by drama teachers of Structuring Drama Work by Jonothan Neelands (1990). This book was originally written to serve as a valuable resource for 
teachers who wanted to have a handy range of activities for their drama lessons. It was intended that teachers, as part of devising sophisticated drama structures, could take some of these 'conventions' as they are called in the book (forum theatre, voices in the head, and some 45 others), and use them as part of the complex structure of the drama sessions. Instead, they lend themselves to becoming the total method of work employed in a drama lesson. Conventions are relatively easy to teach and can bring a degree of 'success' relatively quickly. One can imagine an inexperienced teacher grasping at Neelands' list and saying to him or herself, which conventions shall I use today? When taken out of context, what is missing is the deep theoretical embedding which a teacher needs to make use of them. Of course, it was not the purpose of the book to provide this.

However, there is another pressure on teachers to be convention-minded: the school syllabus itself. It is interesting to note in passing that the Department of Education in the UK has been renamed the Department for Education and Skills and their guidance for Speaking, Listening and Learning at Key Stage 1 and 2 has 'drama' activities included ((DfES, 2003). The drama work focuses on performance and is skills based. Complex 'living through' drama structures are left out. The drama 'strategies' or 'approaches', as they are called, are inevitably selected from the conventions approach, formalised by Neelands: for example, freeze frame, conscience alley, hot-seating, thought tracking, and similar conventions (DfES, 2003). On the 'Initial Teacher Education - English' website, under the section for the preparation of teachers to teach drama, funded by the Teacher Training Agency (a government body), it states:

Knowing and using the dramatic techniques or conventions as they are sometimes referred to, is the key to teaching and learning in drama and underpins the approaches recommended in all of the guidance documents. (DfES, 2003)

The most comprehensive listing and guide to the conventions approach is available in Structuring Drama Work [1].

It would seem that the original idea of Structuring Drama Work becoming an aid to developing complex drama structures has, instead, inadvertently led to this 'bits and pieces' approach to teaching drama for a whole generation of students. I need to emphasise that there is no criticism of Neelands' teaching intended here. He has always based his work on practice and is a most accomplished practitioner with a wide international reputation. Even drawing attention to Structuring Drama Work, Neelands' book, can make it appear as though I am being harshly judgemental of him. But I want to underline that this is not the case. Neelands' own teaching is far more sophisticated than the teaching that can result from a lesson just made up of a mix of conventions. I want to separate what Neelands has 
provided with this book from the misuse that it has been put to. In this respect, I am referring to the unforeseen but unhappy outcome of providing a drama manual in this form.

If I am right, that we are at somewhat of a junction, or rather in a siding, in DIE theory and practice, is there anything in Bond's approach to theatre that could be useful here? I will explore this in the rest of this paper.

In 1990, Ken Byron and I set up the International Centre for Studies in Drama in Education at the University of Central England. Dorothy Heathcote, Gavin Bolton and John Fines were the principal advisers to the centre and I later proposed Edward Bond as the patron. The aim of the Centre was to continue mining the rich developments in drama form invented by Heathcote and Bolton and to bring the leading figures in drama in education and theatre to a position of influence on our work. The choice of Edward Bond from the field of theatre was more of a hunch on my part than based on real knowledge of his work. I had read some of his plays and seen them in production and admired them. However, I could not have explained with any clarity why I saw him as the leading figure in British theatre. Similarly, I had proposed to the National Committee of NATD (National Association for the Teaching of Drama) that we invite Bond and Heathcote to be the keynote speakers at the huge protest conference we organised in 1988, when it became clear that drama was going to be left out of the new National Curriculum for England and Wales. This was the conference where we also invited international delegates and launched the plan to start IDEA. I knew why I thought Heathcote was the leading figure in drama in education but again I could not have explained why I proposed bringing her together with Edward Bond. As patron of the Centre, Bond gave a workshop to our MA students and local teachers once a year and wrote the very important 'Notes on Imagination' as his inaugural address. Over the years I gradually began to understand more of his work.

I came to understand that my hunch was right and that he has developed a new form of theatre. Bond has had a fractious relationship with theatre in England. The National Theatre and the Royal Shakespeare Company used to premiere his plays but after he found that he could not convince them that they were dealing with a new theatre form he refused to let them produce his work. Directors and actors insisted on trying to bring Stanilslavskian or Brecthian techniques to bear on Bond's plays, but these just destroy the plays' power. Instead, the French national theatre has been more of a home and has premiered a number of his plays. In the UK, since 1995, Bond has worked closely with Big Brum Theatre in Education Company in Birmingham and has written six plays for them. The latest of these is a play for primary children which is touring at this present time. Working with Big Brum Theatre in Education company has, to some extent, given him an acting company he can work with to explore his plays in performance and how they need to be directed. This has provided him with another home in the 
theatre. It is extraordinary, but wonderful, that one of the theatre's greatest post-war playwrights gives the world premiere of some of his plays in Birmingham schools.

For Bond, what is happening to the audience in the theatre is his primary concern. Bond is critical of the influence of Stanislavski on realist theatre. He argues that Stanislavski focused the social meaning of realist theatre through the prism of the psychology of the characters in the plays. This reduced his actor training to making a psychological relationship between the actor and the character. This gives the emphasis on the personal in the social: the study of the individual in society, even though the individual in question might stand for a social type. The outcome is that the audience follows the events of the play through what happens to the characters in terms of their personal development. We empathise with them or dislike them. We follow their ups and downs with an emotional response with little space for critical reflection. It is a sensory experience. A Stanislavskian approach to Hedda Gabbler would tend to focus the audience on Hedda's psychology and the tangle of her relationships with Tesman and Thea, rather than on the destructive and reactionary social force she is when she destroys Tesman's manuscript. It is not the focus on 'Now I am burning your child, Thea' that is important but that in destroying the only copy of Tesman's manuscript, she is destroying a uniquely useful contribution to humanity. Chekov's and Ibsen's plays could focus on the social in the personal - that is, to expose how social forces influence and generally dominate who we are and what we do - but the pressure of Stanislavski's methods makes this emphasis impossible.

Bond also argues that Brecht, in trying to correct this orientation, went too far in working to make reason predominate. Empathy and emotion are allowed in Brecht but they must not cloud cold reason and at the crucial moment when Brecht the playwright and the director intervenes with the gestus. The gestus is Brecht's means of breaking any tendency in the audience to drift into empathising with the character and directs the audience's thinking in the 'right' direction, at least according to Brecht. This leads to the distancing or the Verfremdungseffekt. Brecht is clearly concerned to focus on the social in the personal but does not trust the audience to find themselves. Rather, they are put into a critical relationship to the events on stage where they can rise above their usual immersion in the stream of events and be given a perspective on what is wrong with the world. Bond, in one his more trenchant aphorisms, calls alienation 'the theatre of Auschwitz':

I called the theatre of the A-effect the theatre of Auschwitz. Obviously I do not mean this in a simple sense. In a simple sense it is the opposite of true. The Nazis at Auschwitz would have

\footnotetext{
${ }^{1}$ For a full exploration of this idea see Katafiasz (2005) 
exterminated Brecht not staged him. Brecht spent his energies and his life trying to make hellholes such as Auschwitz - or the Gulag - impossible (Bond, 2000: 171).

What does he mean then by this apparently inflammatory remark? He means that reason is not enough. Fascism and the gas chambers were ruled by reason. What was missing was human imagination and human values. As Bond says, 'We desire to reason but reason does not desire.' Bond does not want the audience to sit above the stream as Brecht does, but to be down in the stream, in the social mess we have created and to have to find ourselves in that mess. To sit above the stream puts the audience in a privileged position of being cleverer and wiser than the poor characters in the play. At the end of Mother Courage we cannot but be drawn to empathise with her and yet Brecht will not allow this. In the film version of his directing of Mother Courage, when Mother Courage pays the peasant to bury her daughter, she bows to the peasant to signal the contract is made and then bows to the cart which she is about to drag out to follow the army. Through this gestus, Brecht is insisting we see her as tied to the needs of business, which predominate over all other values she might have. He is attempting to direct how we respond, cutting out our chance to examine how far we are all Mother Courage. It leaves us in the audience clean and clear, which is a gross distortion of reality. Brecht's aim is certainly to expose the social in the personal but Bond argues that his method prevents us from uncovering the social in ourselves. It could be argued that this pursuit, enabling the audience to find and become themselves, is the centre of Bond's theatre form.

Bond's aim is also, as was Brecht's, to find ways for drama to face us up to the social forces which, in the form of ideologies, have entered unbidden into our minds and direct our lives through a sort of mind control. Bond argues that this mind control makes us feel safer: ideology, in taking over our minds, puts a brake on our imagining, stops us asking what is beyond, what is out there in the universe. Yet freed of ideological control however, we face risk; our imaginations allow us to know our insecurity, our frailty, our fragile hold on life, this short breath of the present moment. The nothingness out there, as Bond calls it, has the potential to frighten human beings; death and nothingness await us all, so forces of authority have captured this realm and dictate from it and on its behalf. As Bond (2004) writes, 'Whoever owns nothingness owns you.' The centre of the fight to regain ownership of ourselves is to recover our imaginations from the corruption of ideological impositions:

\section{As Bond puts it:}

The future of our species depends on one and only one thing: that the Imagination of the adult should be as free as the imagination of the child. Then the adult will Imagine the real - that is, 
create value in the world of facts. In doing this the adult will take responsibility for the world: he or she will become part of the map of the world. When adults imagine the real they become human: otherwise they are not human - the Imagination is owned by the state and produced as Ideology, the falsehoods behind which are the fairy tales of murderers (Bond, 2000: 101).

Again Bond (2000: p.130) writes, 'Drama ... has two ends, "know yourself" and "become yourself". Not be yourself, because you must create yourself from what you are'.'

Bond is centrally concerned that drama should offer the possibility, the stimulus, the provocation, for us all to uncover the hidden forces that try to control us, what he calls transcendentalism: all the ideologies that provide all the answers to life's questions (or rather deny the existence of any questions), ideologies such as religion (in any of its forms), fundamentalist ideas (from Bush to Blair to Islam), fascism, patriotism, racism, etc. He is intent on recovering the importance of the individual in the social and the crucial importance of individual responsibility. His theory is based on the belief (and he has always said he may be wrong) that the human child is genetically pre-programmed for survival and this leads to the initial desire to be at home and to seek justice in the world. This, he believes, is latent in all human beings, albeit corrupted beyond recognition in some people, and it is this he tries to reignite in his plays.

The main tool for this is what he calls a Theatre Event. It is related to what Heathcote and Bolton mean by dramatic action and levels of meaning. At the centre of the Theatre Event is the use of some object, action, gesture, etc, or combination of these. He uses objects that do not have strong ideological connotations invested in them, for example, a chair, a spoon, a cup. This deprives the audience of any means of loading the object with meaning before the meaning has been stimulated.

To give an example: in Eleven Vests (Bond 1997), one of the plays he wrote for Big Brum Theatre in Education Company, an 'enemy' soldier is bayoneted to death callously as an act of revenge. This 'enemy' soldier should have known the rest of his troop had surrendered; they had all hung out their white T-shirts as a signal of surrender. His vest, the eleventh, was missing. He had been up on the roof of the tower playing with the remains of a child's train set. Thinking they were still fighting, he has shot an English soldier. He is bayoneted as a result, after he has surrendered. After the English soldier thinks he is dead, the 'enemy' sits up, reaches for the rifle, picks it up, but instead of shooting the man who killed him, he wipes his blood carefully off the bayonet with the vest he had taken off and had been holding up as a sign of his surrender. No explanation is given for this. After he has carefully done this, he is bayoneted again, and he falls back and dies. The object here is the eleventh vest or T-shirt and the action is wiping the bayonet clear of his blood. In the first half of the play the audience sees the soldier who does the bayoneting, as a teenager at school, totally alienated by his head teacher in a series of 
confrontations. Eventually, the student stabs the head teacher. In the second half of the play he is a soldier (still called 'The Student' in the script) and is being taught the occupation of killing. He is seen being driven to a frenzy during bayonet practice. He is forced to clean up his mess afterwards: the straw from the dummies. This is a recurring motif. In the first part, the Head Teacher was constantly trying to get him to clear up the mess he was making and take responsibility for his supposed actions: another pupil's torn jacket, a ripped book. At the end of the play there is the action of 'the enemy' 'clearing up' his own blood from the bayonet.

This is a Theatre Event. Its aim is to stimulate the audience's imagination to seek the reason for the action and to reason out the situation - but not with the directing hand of Brecht's gestus, which indicates how we should think. The audience is left to deal with it or not, as the case may be. The audience is not distanced from their empathetic involvement with the event. They are not 'alienated' as in Brecht. The aim is for the actors, the audience and the characters in the play all to be on the same 'site'. This 'site' has to be one which will make available all the ideological dimensions under scrutiny. The action is aimed to provoke the imagination to seek reason.

Bond's play Olly's Prison was produced in an African country. In the play, in a long opening scene, a father insists that his daughter drinks the cup of tea he has made for her. She refuses. The scene becomes more violent until he strangles her. When this happened the men clapped and cheered and the women wept. There was much to talk about. This is exactly as Bond would have it. He does not want to control the audience's responses as Brecht did. In fact, he has the completely opposite aim: we must take responsibility for ourselves.

This, of course, is only a glimpse of one aspect of his theatre theory and practice, but it is a central one. All I have time for is to indicate a striving for a new form that draws the audience into the play, encouraging empathy and emotion but finding the means for reflection through the Theatre Event, which aims to stimulate the imagination to seek reason and value but which does not distance the audience. All Bond's plays are political, with a small 'p'; none are didactic. He argues that drama cannot teach, but only provide a means for the chance to come closer to reality without looking through the opaque glass of ideology.

So, how does this connect with my unease with the direction of some mainstream drama teaching in the UK, which is where I started? As far as I can see, the major theatre influences on drama in education (DiE) have been from Stanislavski and Brecht, with Boal offering a strange mixture of influences from Brecht and Stanislavski. These have been the major theories of theatre that have come to predominate in 
the West. If they have influenced the development of drama in education as an art form and Bond has developed a new form of theatre, then the question that is raised is how Bond's work might relate to and influence $\mathrm{DiE}$ and whether this can help to take drama in education forward to invent new forms of work. If Bond is right, that neither Brecht nor Stanislavski are sufficient for today's theatre, then can this be true for today's drama in education? The answer to these questions is my pursuit.

There is only space here to give a brief example of Stanislavski's and Brecht's influence on DiE. However, I think the point is not controversial. Let us imagine that a class of adolescents has become interested in some form of drama exploring the impact of a new adult figure in the life of a single parent family. A high percentage of children in the UK are in single parent family units and a common dilemma is the introduction of a new partner by the mother or father. Let us imagine that the situation is one where a teenage girl is coming down to breakfast on the morning after the new man in her mother's life has stayed the night for the first time. The given is that she resents his presence strongly. The drama teacher has chosen some objects belonging to her mother's new man friend: his car keys; his wallet, inside which the drama teacher has inserted a note saying 'Hi, give me a call. Susan' and a phone number, (her mother's name is not Susan); his leather jacket slung carelessly over the back of a chair; his cigarettes and a lighter. Her mother and friend are still upstairs in bed and the teenage girl is invited to come into this space and find what she would do. She is told she may explore anything in the kitchen if she feels she would. As she does so she may take a cigarette and light it, she may take some money out of the wallet, she may find the note, she may hide the car keys and so on, or do none of these things. At a certain point, another pupil comes in as her mother and they explore their dialogue and maybe later the man comes in. The form of this drama is likely to be a form of Stanislavskian realism. It is the dominant form of acting in theatre, films and TV.

In a later sequence, the drama teacher might set the class up in the role of a collective family counselling service, dedicated to trying to help families deal with their crises. Things have come to a head in some way. The daughter has tried to leave home or run away with her boyfriend. The teacher has added the dimension that the man friend is involved in politics and has been encouraging the mother to participate in demonstrations and to read more widely and she has responded avidly to this. The daughter thinks her mother is being brainwashed. The mother has turned to the counselling service for help. The teacher takes the role as one of the counselling group and the family members are invited in one at a time so that the counsellors can hear each side of the story as the different participants interpret it. The form here is a sort of Brechtian distancing, where most of the pupils are no longer in the main event but in a frame distance from that event. I stress 'a sort of Brechtian distancing'. In fact, the only dimension that echoes Brecht is the relationship of the family counsellors to the event. They are sitting 
above the stream and not subject to the weaknesses of the people they are interviewing. They are approaching the event from the predominant perspective of reason. This is the position into which Brecht puts his audiences.

The Stanislavskian realism form cannot provide enough room for reasoning to appear, except in discussion afterwards, and the Brechtian influenced distancing encourages reason and criticism to predominate. The question I am pursuing is: How would a Bondian form of theatre affect this work?

At present, the focus of the drama is on the family members, their values, psychology and how they are interacting. There are plenty of learning areas: How far should a parent be able to lead an independent life? Is it just matter of more skilful handling of the situation or is there something more fundamental in the problem? Should parents keep their personal lives separate and private from their children? However, there is no real focus on the social in the personal; rather the focus is on the personal in the social. A truly Brecthtian, let alone Bondian, approach would involve the reversal of these emphases. Yet, the interesting area is how the Bondian form would appear.

In the time available I can do no more than attempt a sketch of what an answer might be and I recognise this will be quite unsatisfactory as I am still groping in the dark, but it may be enough to whet some appetites to explore further. This is the area of research that I think has rich possibilities.

We may begin to focus on the social in the personal without alienation if teacher's thinking is shifted from the present focus of the drama which is about - 'How can these individuals meet their different needs in one family unit?' - and move it to 'What does it mean to have a home, to be at home in the world?' What if there is a sheet of paper on the kitchen table with a note from the girl's mother saying 'Don't forget to do your homework'? After she has explored the objects in the kitchen the girl makes the heading 'My home'. She mutters this under her breath as she writes. Instead of just writing, she has been asked by the teacher to draw something that stands for home for her. Those watching have to imagine what she has drawn. When her mother comes in, after the talk that might explore the ongoing situation, the mother adds her drawing of what 'my home' would look like. The man, in this later version, an asylum seeker - whom the mother has befriended and who is waiting to hear if he will be offered a home in this country, when he enters - could add his drawing of what a home means to him. None of those watching knows what has been drawn. If all the members of the class have done this in threes then when they come to share some, no one will know what others have drawn. This has the possibility to open up what it means to be at home in the world and where the need to build a wall around us to keep ourselves safe comes from - to explore what is the ideology behind the feeling of insecurity and what drives the need for a home. 
Later, the daughter could find a passport belonging to the mother's boyfriend, with his photo but someone else's name in it. The daughter has to decide whether or not to phone the police. This has the potential to throw the pupils back to their dominant ideological attitudes to asylum seekers. A Theatre Event is possible in relation to what happens later in the drama. If the police arrive searching for the asylum seeker and the man has to leave in a hurry, the student playing this role can be asked to decide what he would give to the woman or the daughter. What he chooses to give/leave behind has the possibility to become a Theatre Event. This is because the children playing the role are not alienated from it and it is working not with words but with images, objects, gestures, or any other non-verbal communication and this makes a space for the young people's imagination to kick in to seek reason and value. The drama raises questions such as: What are they all seeking? Who is the main asylum seeker? Are they all equally asylum seekers? Is it possible to find a safe home in the world?

This form of the drama keeps the empathy alive, makes the imagination work, has used an ordinary object and made it possible to load it with value and brought reason to bear on the situation without moving to a frame distance that puts the reflection from a safe, 'we know the answers' position.

This is a rather crude and brief example, but at this stage in my thinking it is as far as I can go. Hopefully, I will develop my thinking and this is why I started by saying I am likely to frustrate you more than satisfy you.

I have argued that in the UK we are in danger of 'dumbing down' drama. In the National Curriculum and some forms of examination drama, we are reducing a complex art form to a series of comparatively simple activities. It is time to look at the future development of the form in drama in education. The major theatre influences so far have been from Stanislavski and Brecht. If it is true that Bond has developed a new form of theatre, which I believe he has, then I am suggesting the time is ripe for research projects into what this new form might be for drama in education.

Acknowledgements: Many of the ideas on Bond's theatre explored in this paper have come from discussion with the very useful small research group in Birmingham made up of Kate Katafiasz, Bill Roper, Chris Cooper, and myself, all researching into aspects of Edward Bond's work. In particular, Kate Katafiasz has been the source of many of the ideas on Bond's work and I owe her a great debt. The group thinking and inspiration has been, and is, invaluable. What I present here is, of course, my own responsibility. 


\section{References}

Bond, E. (1997). Eleven Vests. London: Methuen.

Bond, E. (2000). The Hidden Plot. London: Methuen.

Bond, E. (2004). Personal letter

DfES (2003). Speaking, Listening, Learning: Working with Children in Key Stages 1 and 2. Ref: DfES 0627-2003 G, Qualifications and Curriculum Authority.

Katafiasz, K. (2005). Alienation is the Theatre of Auschwitz: An exploration of form in Edward Bond's theatre. In Davis, David (ed.) Edward Bond and the Dramatic Child: Edward Bond's Plays for Younger People, pp. 25-48. London, Trentham Books.

Neelands, J. ve Goode, T. (1990). Structuring Drama Work: A Handbook of Available Forms in Theatre and Drama. Cambridge: Cambridge University Press.

[1]http://www.ite.org.uk/ite_topics/drama_secondary/013.php 



\title{
Edward Bond ve Eğitimde Drama*
}

\section{David DAVIS*}

\author{
Birmingham City Üniversitesi
}

$\mathrm{Bu}$ konferansın konusu, eğitimde dramanın dünü, bugünü ve geleceğidir. Öncelikle, bugün bulunduğumuz yere bakmak ve daha sonra tiyatronun, çalışmalarımızın biçimlenmesine yardımcı olan etkilerine kısaca dikkat çekmek ve son olarak da sınıf içi dramada yeni biçimlerin mümkün olduğu ve aslında bu biçimlere ciddi bir ihtiyaç bulunduğunu ifade etmek istiyorum. Kanaatimce bu etkilere tiyatro formundaki güncel gelişmelerde; bu örnekte ise İngiliz oyun yazarı Edward Bond'un tiyatro formunda ortaya koyduğu gelişmelerde de rastlanacaktır. Bu yeni formların ne olduğundan henüz ben de emin değilim. Bu durumun sizin için biraz hayal kırıklığı yaratması muhtemeldir. Ancak sizlere şu an kesin öneriler sunamasam da, bu formların neler olabileceğinin araştırılmasının vaktinin geldiği kanısındayım.

Sizlerle paylaşmak istediğim bu görüşe başlıca iki yoldan ulaştım. Bu yollardan biri, İngiltere'de bazı önemli alanlarda drama formunun teşvik edildiği yöne dair artan kaygılardır. Diğeri ise oyun yazarı Edward Bond'un çalışmalarının bizzat benim üzerimde gittikçe artan etkisi olmuştur.

İngiltere'de eğitimde dramanın hangi yöne doğru ilerlediği konusundaki kaygılarım, birçok göstergeye dayanmaktadır. Aslında eğitimde dramanın teori ve uygulamasında günümüzde bazı zorluklarla karşılaşıldığı kanaatindeyim.

İngiltere'deki öğretmenlik dersleri, yeni öğretmenlere sağlam bir pedagojik temel verme olanağından yoksun bırakılmıştır; oysaki bu temel, paket bir eğitim programı yerine insanları gerçekten eğitmek isteyen her öğretmen için hayati önem taşımaktadır. Üniversitelerdeki ders saatlerinin azaltılarak öğrencilerin okullarda istihdam edilmesi sonucunda öğrenciler, haftanın belirli günlerinde bu işte çırak olarak çalıştırılmakta ve öğretmen becerilerine dair oldukça yüzeysel bilgiler edinmektedir. Okullardaki tüm drama öğretmenleri, pedagojik, drama öğretiminin teori ve pratiği konularında sağlam bir temele sahip olsa ve şimdiki adlarıyla 'stajyerlere' eğitim vermek için yeterli vakitleri olsa bu 'çıraklık eğitimi' iyi sonuçlar verebilir. Ancak bu tür bir 'çıraklık eğitimi', ideal koşullarda bile yeterli zaman ve kaynakların ayrıldığı bir dersin yerini asla tutamaz; çünkü böyle bir ders, sanat ve drama, öğretim, öğrenme ve bilme yolları ile ilgili teorileri öğrencilerin önüne serecek ve bütün bu teoriler öğretmen adayının pratikteki becerilerinin geliştirilmesi yoluyla öğretilecektir. Hedeflenen kazanımların sınanması ve yazılması konusundaki baskı, genellikle dramada öğretilenleri test edilebilir beceriler seviyesine 
indirgemektedir. $\mathrm{Bu}$ ortamda öğretmenlerin kalıplaşmış bir yaklaşıma yönelmeleri anlaşılabilir bir durumdur.

Söz konusu gelişmenin üzerindeki bir etki de drama öğretmenlerinin Jonothan Neelands'in (1990) Structuring Drama Work adlı kitabını yanlış kullanmaları olmuştur. Bu kitap aslında drama derslerinde çok çeşitli yararlı etkinlikler kullanmak isteyen öğretmenlere değerli bir kaynak sağlamak amacıyla yazılmıştır. Kitabın amacı, incelikli drama yapıları tasarlarken öğretmenlerin, kitaptaki adıyla bu 'standart yöntemler' in (forum tiyatrosu, kafa sesleri ve diğer 45 kadar olanı) bazılarını alıp drama derslerinin karmaşık yapısının bir parçası olarak kullanabilmelerini sağlamaktı. Ancak amaçlananın aksine bu yöntemler drama dersinde kullanılan bütün çalışma yöntemi haline gelmektedir. Yöntemlerin öğretimi nispeten kolaydır ve belli bir derecede ‘başarı'yı oldukça çabuk getirebilir. İnsanın gözünün önüne Neelands'in listesini eline alarak kendi kendine, bugün hangi yöntemleri kullansam, diye soran deneyimsiz bir öğretmen geliyor. Bağlamın dışına çıkarıldığında burada eksik olan şey, bir öğretmenin bu yöntemleri kullanması için gerekli olan derin ve oturmuş teorik bilgisidir. Elbette kitabın amacı bunu sağlamak değildir.

Bununla birlikte öğretmenlerin üstünde yöntemci olmaya yönelik bir baskı daha vardır: Okul eğitim programı. Bu arada İngiltere'de Eğitim Bakanlığı'nın adının Eğitim ve Beceri Bakanlığı olarak değiştirildiğini ve 1. ve 2. Temel Evrelerde Konuşma, Dinleme ve Öğrenme konusunda rehberliğe drama etkinliklerinin de dahil edildiğini kaydedelim (DfES, 2003). Drama çalışması performans odaklıdır ve beceriye dayanır. Karmaşık 'sonuna dek yaşama' drama yapıları kapsam dışında bırakılmaktadır. Genel adıyla drama 'stratejileri' ya da 'yaklaşımları' kaçınılmaz olarak Neelands'in biçimlendirdiği yöntem yaklaşımından seçilir: örneğin fotoğraf karesi, bilinç koridoru, sıcak sandalye, düşünce takibi ve benzer yöntemler (DfES, 2003). Teacher Training Agency'nin (Öğretmen Yetiştirme Ajansı) (bir devlet kurumu) mali desteğiyle yayınlanan Initial Teacher Education-İngilizce adlı internet sitesinin, öğretmenlerin drama öğretimine hazırlanmasıyla ilgili bölümde şöyle denmektedir:

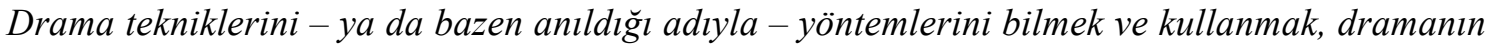
ögretilmesi ve ögrrenilmesinin anahtarıdır ve bütün rehberlik belgelerinde tavsiye edilen yaklaşımların temelinde bunlar yatmaktadır (DfES, 2003).

Standart yöntemler yaklaşımının en kapsamlı listesi ve rehberi, Structuring Drama Work adlı eserde mevcuttur [1].

Structuring Drama Work adlı eserin karmaşık drama yapılarının geliştirilmesine yardımcı olacağına yönelik başlangıçtaki düşünce, aksine istemeden de olsa drama öğretiminde bütün bir öğrenci kuşağ 1 için bu 'parçalı' yaklaşımın doğmasına sebep olmuştur. Burada Neelands'in öğretimini eleştirmek gibi 
bir niyetimin olmadığını vurgulamak istiyorum. Neelands çalışmalarını her zaman uygulama üzerine temellendirmiştir ve tüm dünyada büyük üne sahip olan çok başarılı bir uygulamacıdır. Dikkatleri Neelands'in eseri Structuring Drama Work'e çekmem bile onu acımasızca yargıladığım izlenimini uyandırabilir. Ama kesinlikle böyle olmadığının altını çizmek isterim. Neelands'in öğretim yöntemi, çeşitli yöntemlerin karışımından oluşan bir dersin doğuracağ 1 öğretim yönteminden çok daha ileridir. Neelands'in bu kitapta sunduklarını, kitabın yanlış kullanımından ayrı tutmak istiyorum. Dolayısıyla benim burada söz ettiğim şey, böyle bir drama el kitabı sunulmasının öngörülmeyen fakat üzücü sonucudur.

Eğitimde drama (DIE) teorisi ve uygulamasında bir bakıma bir kavşakta ya da daha doğrusu, bir yan yolda bulunduğumuz konusunda haklıysam, Bond'un tiyatroya yaklaşımında burada yararlı olacak bir şey var mıdır? Konuşmamın geri kalan kısmında işte bu konuyu ele alacağım.

1990 yllında Central England Üniversitesi’nde, Ken Byron ile birlikte Uluslararası Eğitimde Drama Çalışmaları Merkezi'ni (International Centre for Studies in Drama in Education) kurduk. Dorothy Heathcote, Gavin Bolton ve John Fines merkezin baş danışmanlarıydı ve daha sonra ben Edward Bond'un hami olmasını önerdim. Merkezin amac1, Heathcote ve Bolton'ın drama formunda ortaya koydukları zengin gelişmeleri açığa çıkarmaya devam etmek ve eğitimde ve tiyatroda drama alanındaki önemli şahsiyetlerin çalı̧̧malarımızda etki sahibi olmalarını sağlamaktı. Tiyatro alanında Edward Bond seçimi benim açımdan kendisinin çalışmalarıyla ilgili gerçek bir bilgiden çok, bir önseziye dayanıyordu. Edward Bond'un bazı oyunlarını okumuş, sahnede izlemiş ve hayran kalmıştım. Yine de onu neden İngiliz tiyatrosunda önde gelen şahsiyetlerden biri olarak gördüğümü net bir şekilde açıklayamıyordum. Aynı şekilde dramanın Britanya ve Galler bölgesinin yeni Ulusal Eğitim Programı kapsamından çıkarılacağı kesinleşince, NATD (National Association for the Teaching of Drama/Ulusal Drama Öğretimi Derneği) Ulusal Komitesi'ne de 1988 yılında düzenlediğimiz büyük protesto konferansında baş konuşmacılar olarak Bond ve Heathcote'ın davet edilmesini önermiştim. IDEA'yı (Uluslararası Drama, Tiyatro ve Eğitim Derneği) kurma planı da uluslararası temsilcileri de davet ettiğimiz bu konferansla başlamıştır. Heathcote'u drama eğitimi alanındaki en önemli şahsiyet olarak görmemin nedenini biliyordum ama onun neden Edward Bond'la bir araya getirilmesini önerdiğimi açıklayamıyordum. Bond, Merkez'in hamisi olarak yüksek lisans öğrencilerimize ve yöredeki öğretmenlere yılda bir kez atölye çalışmaları düzenledi ve açılış konuşması olarak da 'Notes on Imagination' (Yaratıcılık Üzerine Notlar) adlı o çok önemli metnini yazdı. Onun çalışmalarını yıllar geçtikçe daha iyi anlamaya başladım.

Önsezimde haklı olduğumu ve Bond'un yeni bir tiyatro formu geliştirdiğini anlamaya başlamıştım. Bond'un İngiltere'deki tiyatroyla arası pek iyi değildi. Ulusal Tiyatro ve Royal Shakespeare Company 
(Shakespeare Kraliyet Topluluğu) Bond'un oyunlarının galalarını yapardı ama Bond, onları yeni bir tiyatro formuyla karşı karşıya olduklarına ikna edemediğini fark edince oyunlarını sahnelemelerine izin vermedi. Yönetmenlerle oyuncular Bond'un oyunlarına Stanislavski ya da Brecht'in tekniklerini uygulamakta 1srar ediyor ama tüm bunlar sadece oyunların gücünü mahvetmekten başka bir işe yaramıyordu. İngiliz Tiyatrosunun aksine Fransız Ulusal Tiyatrosu, Bond'a daha fazla sahip çıkarak birçok oyununun galasına ev sahipliği yapmıştır. Bond, İngiltere'de 1995'ten bu yana Birmingham'daki Big Brum Theatre in Education Company (Big Brum Eğitim'de Tiyatro Topluluğu) ile yakın bir ilişki içinde çalışmaktadır ve bu topluluk için altı oyun yazmıştır. $\mathrm{Bu}$ oyunların en sonuncusu, ilkokul çocukları için yazılmış olup şu anda turnesi yapılmakta olan bir oyundur. Bond, Big Brum Theatre in Education Company ile yaptığı çalışmalar sayesinde, bir ölçüde oyunlarını sahnede izlemek ve oyunlarının nasıl yönetilmesi gerektiğini görmek üzere bir tiyatrocular topluluğuyla çalışma olanağ1 bulmuş ve böylece tiyatro alanında kendine bir ev daha bulmuştur. Savaş dönemi sonrası tiyatronun en büyük oyun yazarlarından birinin bazı oyunlarının dünya galasını Birmingham okullarında gerçekleştirmesi sıra dışı fakat harika bir olaydır.

Bond'un öncelikli kaygısı tiyatroda seyirciye neler olduğudur. Bond, Stanislavski'nin realist tiyatro üzerindeki etkisini eleştirmektedir. Stanislavski'nin realist tiyatronun sosyal anlamını oyundaki karakterlerin psikolojisinin süzgecinden geçirdiğini öne sürmektedir. Böylece Stanislavski’nin oyuncu eğitimi, karakter ve oyuncu arasında psikolojik bir ilişki kurulmasından ibaret kalmakta ve toplumsalın içindeki bireysel- yani söz konusu birey herhangi bir sosyal sınıfı temsil edebilirse bile, toplum içindeki bireyin araştırılması - vurgulanmaktadır. Sonuçta seyirci; oyundaki olayları, kendi kişisel gelişimleri açısından karakterlerin başına neler geldiği açısından takip eder. Kendimizi karakterlerle özdeşleştirir ya da onları sevmeyiz. Onların inişlerini ve çıkışlarını, eleştirel düşünceye yer bırakmayan bir duygusal tepkiyle izleriz. Bu, duyumsal bir deneyimdir. Örneğin Hedda Gabbler'a Stanislavskivari bir yaklaşım, seyirciyi büyük olasılıkla Tesman'ın el yazmasını yok edişindeki yıkıcı ve gerici sosyal güce değil, Hedda'nın psikolojisine ve Tesman ve Thea ile aralarındaki çapraşık ilişkiye odaklanmaya sevk edecektir. Halbuki odaklanılması gereken önemli nokta, 'Şimdi senin çocuğunu yakıyorum, Thea,' değil, Hedda'nın Tesman'ın el yazmasının tek nüshasını yok ederek insanlığa eşsiz derecede yararlı bir katkıyı yok ediyor oluşudur. Çehov ve Ibsen'nin oyunları toplumsal güçlerin nasıl kimliğimize ve yaptıklarımıza etki eden, genellikle de hükmeden güçler olduğunu açığa çıkarmak amacıyla - bireyselin içindeki toplumsala odaklanabilmektedir; ama Stanislavski'nin kullandığı yöntemlerin baskısı bunun vurgulanmasını imkânsız kılmaktadır.

Bond aynı zamanda Brecht'in de bu yönelimi düzeltmeye çalışırken, aklı üstün kılma çabasında çok ileri gittiğini öne sürmektedir. Brecht'in eserlerinde empati ve duyguya yer vardır ama bunlar nesnel aklı 
gölgelememelidir; özellikle de oyun yazarı ve yönetmen Brecht'in gestus ile araya girdiği o can alıcı anda. Gestus ${ }^{*}$; Brecht'in, seyircinin karakterle özdeşim kurmaya yönelik her türlü eğilimine son vermek ve seyircinin düşüncelerini - en azından Brecht'e göre - 'doğru' yöne yönlendirmek için kullandığ araçtır. Bu aracın kullanılması, uzaklaştırmaya ya da "Verfremdungseffekt'e", (yabancılaştırma etkisi) yol açar. Brecht'in bireyselin içindeki toplumsala odaklanma kaygısı olduğu açıktır ama bunu kendi kendine bulması konusunda seyirciye güvenmez. Aksine seyirciler sahnedeki olaylarla eleştirel bir ilişki içine sokulur ve bu ilişkide olayların akışına olağan dalışlarından sıyrılarak dünyada nelerin yanlış gittiğine dair bir perspektif edinebilirler. Bond, daha keskin aforizmalarının birinde, yabancılaştırmayı 'Auschwitz Tiyatrosu'”.. olarak adlandırır:

A-etkisi tiyatrosunu Auschwitz tiyatrosu olarak adlandirdim. Bunu basit bir anlamda kullanmadı̆̆ım açıtıtır. Basit bir anlamda bu, gerçeğin zıddıdır. Öyle olsa Auschwitz'deki Naziler oyunlarını sahnelemez, Brecht'i yok ederlerdi. Brecht, enerjisini ve hayatını Auschwitzya da Gulag - gibi cehennem çukurlarını olanaksız hale getirmeye harcamıştır (Bond, 2000: 171).

O halde Bond görünürde kışkırtıcı bu ifadeyle ne demek istemiştir? Demek istediği şey, aklın yeterli olmadığıdır. Faşizm ve gaz odalarına akıl egemendi. Eksik olansa insan yaratııılığı ve insani değerlerdi. Bond'un da dediği gibi, 'Biz aklı arzularız ama akıl arzulamaz.' Bond, Brecht'in istediği gibi seyircinin akışın ötesinde değil, bizzat içinde olmasını; kendi yarattığımız toplumsal kargaşanın içinde olup bu kargaşa içinde kendimizi bulmak zorunda kalmamızı ister. Akışın ötesinde olmak, seyirciyi oyundaki zavallı karakterlerden daha akıllı ve bilge olduğu ayrıcalıklı bir konuma getirir. Cesaret Ana'nın sonunda kendimizi onun yerine koymaktan alıkoyamayız fakat Brecht buna asla izin vermeyecektir. Cesaret Ana'nın kendi yönettiği film uyarlamasında, Cesaret Ana, köylüye kızını gömmesi için para verirken, anlaştıklarını anlatırcasına köylüye reverans yapar; ardından ordunun peşinden gitmek üzere götüreceği arabaya da bir reverans yapar. Bu gestus aracılığıly, Brecht 1srarla bizim, Cesaret Ana’y1 sahip olabileceği diğer bütün değerlerden üstün tuttuğu ticaretin gerekliliklerine bağlı biri olarak görmemizi istemektedir. Ne kadar Cesaret Ana olduğumuzu düşünme imkânını elimizden alarak tepkilerimizi yönetmeye çalışmaktadır. Onun bu çabası bizi tamamen birer seyirciden ibaret kılar; bu ise gerçeğin tam anlamıyla çarpıtılmasıdır. Brecht'in amacı kuşkusuz bireyselin içindeki toplumsalı açığa çıkarmaktır ama Bond, onun yönteminin kendi içimizdeki toplumsalı ortaya çıkarmamızı engellediğini

\footnotetext{
* Brecht'in epik tiyatro kuramının en önemli ögelerinden biri olan "gestus" kavramının anlam çerçevesi, her ne kadar aynı kökten türese de, dilimizde önerilen karşılıkları olan "jest”, "toplumsal jest” ya da "toplumsal davranış" gibi terimlerle ifade edilemeyecek kadar geniştir. Sadece jest veya davranış anlamını aşan gestus, bir insanın bir başkası karşısındaki tutumunun akla gelebilecek bütün ifadelerini kapsar: ses tonu, yüz ifadesi, bedenin konumu, bir insanın bir başkası önünde konuşma ve duruş biçimi, ona gösterdiği tepkiler gibi.

${ }^{* *}$ Kelimenin baş harfinden dolayı V-effekt yani V-etkisi de denmektedir. Aynı şekilde terimin İngilizce karşılığı olan "alienation effect" içinse biraz aşağıda Bond'un alıntılanan sözlerinde de görüleceği gibi A-effect’in karşılığı olarak A-etkisi terimini kullandık. A-etkisi terimini Auschwitz ile aynı harfle başlamasından dolayı kullandık; Türkçe'de Y-etkisi (yabancılaştırma etkisi) ile karşılanması daha doğru olacaktır.

... Bu düşünceyle ilgili ayrıntılı bir inceleme için, bkz. Katafiasz (2005).
} 
öne sürer. Bu çabanın, yani seyircinin kendini bulup kendisi olmasını sağlamanın Bond'un tiyatro formunun merkezi olduğu söylenebilir.

Bond'un bir amacı da, tıpkı Brecht gibi, ideoloji formunda zihinlerimize davetsizce girip yerleşerek bir tür zihin kontrolü yoluyla yaşamlarımızı yönlendiren toplumsal güçlerle bizi yüzleştirecek drama yöntemleri bulmaktır. Bond, bu zihin kontrolünün kendimizi daha güvende hissetmemizi sağladığını öne sürmektedir: ideoloji, zihinlerimizi ele geçirerek hayal gücümüzü frenler; ötelerde, evrende neler olduğunu sorgulamaktan bizi alıkoyar. Fakat ideolojik kontrolden kurtulduğumuzda da yine tehlikeyle karşı karşıya kalırız; hayal gücümüzle güvensizliğimizin, güçsüzlüğümüzün, hayatla aramızdaki kırılgan bağın, içinde bulunduğumuz anın kısalığının bilincine varırız. Bond'un dediği gibi, dışarıdaki hiçlik insanları ürkütebilir; hepimizi ölüm ve hiçlik bekliyor, bu yüzden otoriter güçler bu alanı ele geçirmiştir ve oradan ve onun adına egemenliğini icra eder. Bond'un da (2004) yazdığı gibi 'Hiçliğe sahip olan, sana da sahiptir.' Benliğimizin sahipliğini geri kazanma savaşının merkezinde hayal gücümüzü ideolojik dayatmaların tahriplerinden kurtarmak yatmaktadır:

Bond şöyle der:

Türümüzün geleceği sadece ve sadece tek bir şeye bağlıdır: Yetişkinlerin hayal gücü, çocuklarınki kadar özgür bırakılmalıdır. Işste o zaman yetişkinler gerçek olanı hayal edecektir yani gerçekler dünyasında değer yaratmayl. Yetişkinler böylelikle dünyanın sorumluluğunu yüklenir: dünya haritasının bir parçası olurlar. Yetişkinler gerçek olanı hayal ettiklerinde insana dönüşür: aksi takdirde insan olamazlar - Hayal gücü devletin tekelindedir ve Ídeoloji olarak; ardında canilerin masalları yatan aldatmacalar olarak üretilir (Bond, 2000: 101).

Bond (2000: 130) yine der ki: 'Dramanın ... iki amacı vardır, "kendini bil" ve "kendine dön". Kendin $o l$ değil, çünkü kendinizi, ne iseniz ondan yaratmalısınız.'

Bond'un esas kaygısı şudur: drama, hepimizi kontrol etmeye çalışan gizli güçleri - kendi deyişiyle transandantalizm (aşkıncılık) - açığa çıkarmak için bize olanak, teşvik, tahrik sunmalıdır: yani yaşamın bütün sorularını yanıtlayan (ya da daha çok bütün soruların varlığını reddeden) tüm ideolojileri; din gibi ideolojileri (tüm formlarıyla); köktendinci fikirleri (Bush'tan Blair'e ve İslam'a kadar); faşizm, vatanseverlik, ırkçılık vb. ideolojileri. Bond, toplumsal içindeki bireyselin önemini ve bireysel sorumluluğun hayati önemini geri kazanmaya azmetmiştir. Bond'un teorisi, (yanılabileceğini her zaman belirtir) insanoğlunun çocukluktan genetik olarak hayatta kalmaya programlandığı ve bunun da ilk olarak evde olma ve dünyada adaleti arama arzusuna yol açtığı inancına dayanmaktadır. Ona göre bu arzu, bazı insanlarda tanınmayacak kadar bozulmuşsa da, her insanın içinde potansiyel olarak bulunur ve Bond'un oyunlarında yeniden alevlendirmeye çalıştı̆̆ düşünce de işte budur. 
Bunun temel aracı, kendisinin deyişiyle Tiyatro Olayıdır. Heathcote ve Bolton'ın dramatik eylem ve anlam düzeyleri derken kastettikleri şeyle ilişkilidir. Tiyatro Olayının merkezinde bir nesne, eylem, jest vb. ya da bunların hepsinin bir kombinasyonun kullanılması yatmaktadır. Bond, güçlü ideolojik çağrışımlar yüklenmemiş nesneleri kullanır; örneğin sandalye, kaşık, fincan. Böylece anlam harekete geçirilmeden önce nesneye herhangi bir anlam yükleme imkânını seyircinin elinden alır.

Bir örnek vermek gerekirse: Big Brum Eğitim'de Tiyatro Topluluğu için yazdığı oyunlardan biri olan Eleven Vests'te (Bond, 1997), bir 'düşman' askeri intikam uğruna acımasızca süngülenerek öldürülmektedir. $\mathrm{Bu}$ 'düşman' askerinin kendi taburunun geri kalanının teslim olduğunu bilmesi gerekirdi; taburdaki askerlerin hepsi de teslim olduklarını anlatmak için beyaz tişörtlerini havaya kaldırmıştı. On birinci atlet, yani onun atletiyse eksikti. Halbuki bu asker o sırada kulenin çatısına çıkıp bir çocuğun oyuncak treninden geriye kalan parçalarla oynamaktaydı. Savaşa devam ettiklerini düşünerek bir İngiliz askerini vurdu. Bunun sonucunda da, teslim olduktan sonra süngülendi. İngiliz asker onun öldüğünü düşünürken, 'düşman' yattığı yerden doğrularak tüfeğini eline alıp havaya kaldırdı; ama kendisini öldüren adamı vurmak yerine, daha önce çıkarıp teslim olduğunu anlatmak için havaya kaldırdığı atletiyle süngüdeki kendi kanını dikkatlice sildi. Bu harekete hiçbir açıklama getirilemez. 'Düşman' bu işi özenle tamamladıktan sonra, bir kez daha süngülendi ve yere düşerek öldü. Buradaki nesne on birinci atlet ya da tişörttür ve eylem de süngüdeki kanın silinmesidir. Oyunun ilk yarısında seyirci, süngüleme işini yapan askeri okula giden bir genç gibi görür; bu genç, aralarındaki bir dizi çatışmadan dolayı başöğretmenine tamamen yabancılaşmıştır. En sonunda öğrenci, başöğretmeni bıçaklar. Oyunun ikinci yarısında ise artık askerdir (senaryoda hâlâ ‘Öğrenci’ diye geçer) ve öldürme mesleği öğretilmektedir ona. Süngü talimlerinde kendini kaybettiği görülür. Talimlerden sonra da arkasında bıraktığı dağınıklığı -kuklalardan etrafa dağılan saman çöplerini - temizlemesi istenir. Bu, oyunda tekrarlanan bir temadır. Birinci bölümde, Başöğretmen sürekli öğrenciye neden olduğu dağınıklığı toplattırmaya ve yaptığı sanılan eylemlerin sorumluluğunu - başka bir öğrencinin sökülen ceketi, yırtılan bir kitap - üstlenmesini sağlamaya çalışır. Oyunun sonunda ise 'düşman'ın kendi kanını süngüden 'silmesi' eylemi vardır.

İşte bu bir Tiyatro Olayıdır. Amacı, seyircinin hayal gücünü eylemin nedenini aramaya, durumu çözümlemeye teşvik etmektir - ama Brecht'in gestusunun nasıl düşünmemiz gerektiğini bildiren yönetmen eliyle değil. Onunla baş etmek ya da etmemek seyirciye bırakılır. Seyirci, olayla kurduğu empatik bağdan uzaklaştırılmaz. Brecht'te olduğu gibi 'yabancılaştırılmaz'. Oyuncular, seyirciler ve oyundaki karakterler için amaç, hepsinin aynı 'konum'da olmalarıdır. Bu 'konum' bütün ideolojik boyutları sorgulanmaya hazır hale getirmelidir. Eylemin amacı, hayal gücünü neden aramaya teşvik etmektir. 
Bond'un Olly's Prison adlı oyunu bir Afrika ülkesinde doğmuştur. Oyunda, uzun bir açılış sahnesinde bir baba, kızına hazırladığı bir fincan çayı içmesi konusunda 1srar etmektedir. Ama kız içmek istemez. Sahne giderek şiddetlenir ve sonunda baba, kızını boğazlar. Bunun üzerine erkekler alkışlayıp sevinç çığlıkları atmış; kadınlarsa ağlamıştır. Konuşulacak çok şey vardır. Bond'un istediği şey de tam olarak budur. O, Brecht gibi seyircinin tepkilerini kontrol etmek istemez. Aslında Bond'un amac1 Brecht'inkinin tamamen zıddıdır: kendi sorumluluğumuzu üstlenmemiz gerekir.

Burada tabii ki Bond'un tiyatro teorisi ve uygulamasının tek bir yönüne göz attık sadece ama bu, önemli bir yöndür. Bu kadar zamanda, bütün Tiyatro Olayı boyunca empati ve duyguyu körükleyerek ama aynı zamanda düşünceye yollar da bularak seyirciyi oyunun içine çeken yeni bir form çabasına dikkat çekebilirim ancak; bu Tiyatro Olayı, hayal gücünü aklı ve değeri aramaya teşvik eder ama seyirciyi de uzaklaştırmaz. Bond'un tüm oyunları - küçük 'p' ile - politiktir; hiçbiri didaktik değildir. Bond, dramanın hiçbir şey öğretemeyeceğini; sadece puslu ideoloji gözlüğünden bakmadan gerçekliğe yaklaşma olanağı veren bir araç sunduğunu öne sürer.

Şu halde bütün bunların başladığım noktada söz ettiğim o rahatsızlıkla; İngiltere'de ana eğilime mensup bazı drama öğretimi tekniklerinin yönelimiyle nasıl bir bağlantısı vardır? Anladığım kadarıyla, tiyatronun eğitimde drama (DiE) üzerindeki başlıca etkileri Stanislavski ve Brecht'ten gelmektedir; Boal da Brecht ve Stanislavski etkilerinin tuhaf bir karışımını sunmuştur. Bunlar, Batı'ya egemen olmaya başlayan temel tiyatro teorileridir. Bunlar bir sanat dalı olarak eğitimde dramanın gelişimini etkilediyse ve Bond da yeni bir tiyatro şekli geliştirdiyse, o zaman ortaya atılan soru; Bond'un çalışmalarının eğitimde dramayla nasıl bir ilişkisi olabileceği ve eğitimde dramayı nasıl etkileyebileceği ve bunun yeni çalışma formları bulmak üzere eğitimde dramayı daha ileri taşımaya yardımcı olup olamayacağı olur. Eğer ne Brecht ne de Stanislavski'nin bugünün tiyatrosu için yeterli olmadıkları konusunda Bond haklıysa, aynı şey bugünün eğitimde draması için de geçerli midir? İşte ben bu soruların yanıtlarının peşindeyim.

Burada sadece, Brecht ve Stanislavski'nin eğitimde drama üzerindeki etkilerine kısa bir örnek vermeye olanağımız var. Ancak bence konu tartışmalı değil. Bir sınıf dolusu ergenin, yeni erişkin figürünün tek ebeveynli bir ailenin yaşamındaki etkisini araştıran bir drama şekliyle ilgilenmeye başladığını hayal edelim. İngiltere'deki çocukların büyük çoğunluğu tek ebeveynli ailelerde yaşamaktadır ve anne ya da baba tarafından tanıştırılan yeni bir partner, bu çocuklar için ortak bir ikilemdir. Genç bir kızın, annesinin hayatındaki yeni erkeğin ilk defa evlerinde kaldığı gecenin sabahında, kahvaltıya indiği bir durumu düşünelim. Burada verilen, genç kızın adamın varlığına çok içerlemiş olmasıdır. Drama öğretmeni, annesinin yeni erkek arkadaşına ait bazı nesneler seçmiştir: arabasının anahtarları; öğretmenin içine 'Merhaba, beni ara. Susan' ve telefon numarası yazılı bir not 
bıraktığı cüzdanı (annesinin adı Susan değil); sandalyenin arkasına özensizce fırlatılmış deri ceketi; sigarası ve çakmağı. Annesiyle erkek arkadaşı hala yukarıda yataktadır ve genç kız bu ortama çağrılarak ondan ne yapacağını bulması istenir. Kıza eğer isterse mutfaktaki her şeyi araştırabileceği söylenir. Bunu yaparken bir sigara alıp yakabilir, cüzdandan biraz para aşırabilir, notu bulabilir, arabanın anahtarlarını saklayabilir vs. ya da bunların hiçbirini yapmaz. Belli bir noktada; başka bir öğrenci, kızın annesi olarak gelir ve diyaloga girerler; belki daha sonra adam da gelir. Bu drama formunun, Stanislavski realizminin bir formu olması olasıdır. Televizyonda, filmlerde ve tiyatroda baskın oyunculuk şekli de budur.

Daha sonraki bir sahnede, drama öğretmeni, buhranlarıyla başa çıkmaları konusunda ailelere yardım eden bir aile danışmanları topluluğu rolünde oynatabilir sınıfı. İşler artık dönüm noktasına gelmiştir. Genç kız evden ayrılmayı ya da erkek arkadaşıyla birlikte kaçmayı denemiştir. Öğretmen dramaya bir boyut daha ekler: erkek arkadaş politikayla ilgilenmektedir ve anneyi eylemlere katılarak daha geniş çapta okumaya teşvik etmiş; kadın da buna olumlu karşılık vermiştir. Genç kız, annesinin beyninin yıkandığını düşünmektedir. Anne, yardım için kurulan danışmanlık topluluğuna başvurur. Öğretmen danışmanlık gruplarından biri rolünü üstlenir ve aile bireyleri tek tek içeri çağrılır; böylece danışmanlar, farklı katılımcıların yorumlarıyla hikâyenin tüm yönlerini onların ağzından dinleyecektir. Buradaki form, Brechtvari bir tür uzaklaştırmadır; öğrencilerin çoğu artık olayın içinde değil, olaydan belli bir mesafe uzaklıktadır. 'Brechtvari bir tür uzaklaştırma'nın altını çizelim. Aslında burada Brecht'i taklit eden tek boyut, aile danışmanlarının olayla olan ilişkisidir. Danışmanlar, akışın ötesinde durmaktadır ve görüştükleri kişilerin zayıflıklarına tabi değildirler. Onlar olaylara aklın üstün bakış açısıyla yaklaşmaktadır. Brecht'in seyircilerini getirdiği konum da işte budur.

Sonraki tartışmaların haricinde, Stanislavski realizmi, akıl yürütmeye fazla imkân bırakmaz; Brecht'in etkili uzaklaştırması ise aklı ve eleştiriyi egemen olmaya teşvik eder. Peşinde olduğum soru şudur: Bondvari bir tiyatro formu, bu çalışmayı nasıl etkileyecektir?

Şu anda drama; aile bireyleri, onların değerleri, psikolojisi ve birbirlerini nasıl etkiledikleri üzerinde odaklanmaktadır. Pek çok öğrenme alanı mevcuttur: Bir ebeveyn, bağımsız bir yaşam sürmekte ne kadar ileri gitmelidir? $\mathrm{Bu}$, sadece durumu ustalıkla idare etmekle ilgili bir mesele midir yoksa sorunun içinde daha esaslı bir şey mi vardır? Ebeveynler özel hayatlarını çocuklarından gizli ve ayrı mı tutmalıdır? Bununla birlikte bireyselin içindeki toplumsala gerçekten odaklanılmaz; odak konusu daha çok toplumsalın içindeki bireydir. Bond'un yaklaşımı bir yana, gerçekten Brecht'e özgü bir yaklaşım, bu vurguları tersine döndürecektir. Ama ilginç olan, Bond'a özgü formun nasıl ortaya çıacağıdır.

Mevcut sürede, cevabın ne olabileceğine dair ancak bir taslak çizebilirim ve hala karanlık bir alanda dolaştı̆̆ım için, bunun oldukça yetersiz kalacağının farkındayım, ama yine de daha fazla araştırmak için 
iştahları kabartmaya yeterli olabilir. Zengin olanakları bulunduğuna inandığım araştırma alanı işte budur.

Şayet öğretmenin düşüncesi dramanın mevcut odak konusundan - 'bu bireyler, tek bir aile birimi içinde farklı ihtiyaçlarını nasıl karşılar?' - uzaklaşarak 'dünyada bir eve sahip olmak, evinde olmak ne anlama gelir?'e kayarsa, yabancılaşmadan bireyselin içindeki toplumsala odaklanmaya başlayabiliriz. Ya mutfak masasının üstünde kızın annesinden ‘ödevlerini yapmayı sakın unutma’ yazılı bir not varsa? Mutfaktaki nesneleri araştırdıktan sonra, genç kız 'Evim’ başlığını atar. Genç kız yazarken bunu sessizce mırıldanır. Sadece yazmak yerine, öğretmen kızdan, ona göre evi simgeleyen bir şeyler çizmesini de ister. İzleyenler de kızın ne çizdiğini bulacaktır. Annesi geldiğinde, devam eden durumu ortaya koyabilecek olan bir konuşmadan sonra, anne de kendi 'evim' çizimini ekler. Bu sonraki uyarlamada adam da - annenin arkadaş olduğu ve geldiği bu yerde kendisine bir ev sunulup sunulmayacağını öğrenmeyi bekleyen - bir sığınmacı olarak evin kendisi için ne ifade ettiğini anlatan çizimini ekleyebilir. İzleyenlerden hiçbiri neler çizildiğini bilmez. Sınıfın bütün üyeleri bunu üçerli şekilde yaparsa, sonra bazılarını paylaşmaya sıra geldiğinde, kimse diğerinin ne çizdiğini bilmeyecektir. Böylece insanın dünyada evinde olmasının ne anlam ifade ettiğini ve kendimizi güvende hissetmek için etrafımıza duvar örme ihtiyacının nereden geldiğini - güvensizlik düşüncesinin ardındaki ideolojinin ne olduğunu ve ev ihtiyacının nereden kaynaklandığını araştırma - ortaya çıkarma imkânı doğar.

Daha sonra genç kız, annesinin erkek arkadaşına ait bir pasaport bulabilir; pasaportun üzerinde adamın fotoğrafı ama başkasının ismi vardır. Kız polisi arayıp aramayacağına karar vermek zorundadır. Bu olay, öğrencileri, sığınmacılar hakkındaki baskın ideolojik tutumlarına geri döndürme potansiyeline sahiptir. Bir Tiyatro Olayı, dramada daha sonra neler olacağı bağlantısıyla mümkündür. Polis sığınmacıyı aramaya gelirse ve adam da aceleyle gitmek zorunda kalırsa, bu rolü oynayan öğrenciden kadına ya da kıza ne vereceğine karar vermesi istenebilir. Vermeyi/ bırakmayı seçtiği şeyin, bir Tiyatro Olayına dönüşme olasılığı vardır. Çünkü rolü oynayan çocuklar, role yabancılaştırılmaz ve bu da kelimelerle değil ancak imgeler, objeler, jestler ya da başka tür bir sözsüz iletişim aracıllğıyla olur. Bu da gençlerin hayal gücünde aklı ve değeri aramak konusunda imkânlar doğurur. Drama şöyle sorular sordurur: Herkes neyi arıyor? Asıl sığınmacı kim? Herkes aynı derecede sığınmacı mı? Dünyada güvenli bir ev bulmak mümkün mü? Böyle bir drama formu empatiyi canlı tutar, hayal gücünü çalıştırır, sıradan bir nesneyi alarak buna değer yüklenmesini mümkün kılar ve güvenli bir 'biz yanıtları biliyoruz' tavrından düşünceyi öne süren mesafeli duruşa geçmeksizin, duruma akıl yürütmeyi getirir.

Bu kısa ve biraz ham bir örnek olsa da, bu aşamada düşüncemde bu noktaya kadar gelebiliyorum. Düşüncemi geliştireceğimi umut ediyorum. Konuşmama sizi tatmin etmekten çok hayal kırıklığına uğratacağa benziyorum diyerek başlamamın nedeni de buydu. 
İngiltere'de dramayı 'basite indirgeme' tehlikesiyle karşı karşıya olduğumuzu iddia ediyorum. Ulusal Eğitim Programında ve bazı drama sınavlarında, karmaşık bir sanat dalını çok daha basit bir etkinlikler dizisine indirgiyoruz. Artık eğitimde drama biçimlerinin gelecekteki gelişimlerine bakma zamanı gelmiştir. Bugüne kadarki büyük tiyatro etkileri Stanislavski ve Brecht'ten gelmiştir. Bond'un yeni bir tiyatro formu geliştirdiği doğruysa, ki ben öyle olduğuna inanıyorum, o halde bence bu yeni formun eğitimde drama için ne olacağı konusunda araştırma projeleri yapılmasının zamanı gelmiştir.

Takdim ve teşekkür: Bond'un tiyatrosu hakkında bu sunumda araştırılan düşüncelerin çoğu; Kate Katafiasz, Bill Roper, Chris Cooper ve bendenizden oluşan, Edward Bond'un çalışmalarının etkilerini inceleyen Birmingham'daki çok yararlı ve küçük bir araştırma grubundan gelmektedir. Özellikle Kate Katafiasz, Bond'un çalışmaları hakkındaki birçok fikre kaynaklık etmiştir; bu yüzden kendimi ona borçlu sayiyorum. Grubun düşünüşü ve gruptan aldığım ilhama paha biçilemez. Burada sunduğum her şey ise elbette ki benim sorumluluğumdadır.

\section{Kaynaklar}

Bond, E. (1997). Eleven Vests. London: Methuen.

Bond, E. (2000). The Hidden Plot. London: Methuen.

Bond, E. (2004). Personal letter.

DfES (2003). Speaking, Listening, Learning: Working with Children in Key Stages 1 and 2. Ref: DfES 0627-2003 G, Qualifications and Curriculum Authority.

Katafiasz, K. (2005). Alienation is the Theatre of Auschwitz: An exploration of form in Edward Bond's theatre. In Davis, David (ed.) Edward Bond and the Dramatic Child: Edward Bond's Plays for Younger People, pp. 25-48. London, Trentham Books.

Neelands, J. ve Goode, T. (1990). Structuring Drama Work: A Handbook of Available Forms in Theatre and Drama. Cambridge: Cambridge University Press.

[1](http://www.ite.org.uk/ite topics/drama_secondary/013.php). 
